\title{
IAMJ
}

INTERNATIONAL

AYURVEDIC

MEDICAL JOURNAL

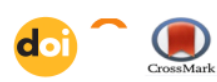

Research Article

ISSN: 2320-5091

Impact Factor: 6.719

\section{CLINICAL STUDY OF GUGGULU GOLD AND GUM SHALLAKI ALONG WITH PANCHKARMA THERAPIES IN THE MANAGEMENT OF SANDHIGHATA VATA W.S.R OSTEOARTHRITIS}

\author{
Nishu Raina \\ Assistant Professor In Kayachikitsa, DAC, Jalandhar, Punjab, India \\ Corresponding Author: nishu.raina2010@gmail.com
}

https://doi.org/10.46607/iamj01p5062021

(Published online: September 2021)

Open Access

(C) International Ayurvedic Medical Journal, India 2021

Article Received: 05/08/2021 - Peer Reviewed: 23/08/2021 - Accepted for Publication: 24/08/2021

Check for updates

\begin{abstract}
In Vriddhavastha, most of the Dhatus Kshaya, which in turn leads to Vataprakopa and thus making individuals prone to many diseases. Among these diseases, Sandhigata Vata is one type of Vata-Vyadhi, which is the commonest form and occurs mainly due to sitting jobs, air conditioner atmosphere, lack of proper healthy diet, travelling and old age etc. Sandhigata Vata is one of the most common Vatavyadhi, which can be correlated with osteoarthritis. The prevalence rate of Osteoarthritis is about $14.8 \%$, in which knee osteoarthritis prevalence rate is $10.8 \%$ which is more than the arthritis of other joints ${ }^{1}$. The incidence of osteoarthritis in India is as high as $12 \%$. It is estimated that approximately four out of 100 people are affected by it. Osteoarthritis is the most common articular disorder which begins asymptomatically in the $2^{\text {nd }} \& 3^{\text {rd }}$ decades and is extremely common by age 70 . Almost all persons by age 40 have some pathologic change in the weight-bearing joint. $25 \%$ of females \& $16 \%$ of males have symptomatic osteoarthritis. When we talk about healthy joints, there is a coating of tough but smooth and slippery tissue, called cartilage, which covers the surface of the bones and helps the bones to move freely against each other. When a joint develops osteoarthritis, part of the cartilage thins and the surface becomes rougher, which in turn doesn't allow the joint to move as smoothly as it should. When cartilage becomes damaged, all the tissues within the joint become more active than normal as the body tries to repair itself. But these repair processes are going to change not only the structure of the joint but will often allow the joint to work normally and without any pain and
\end{abstract}


stiffness. Acharya Charaka has mentioned "Sandhi Gataanila", which means vata gets located in the Sandhi and thereafter results in Sandhigatavata. Allopathic treatment has its limitation in managing this disease. It can provide either conservative or surgical treatment and can only subside the pain but not cure the cause of diseases. While traditional life science Ayurveda has the most effective solution over this. Local Abhyanga and Nadi Sweda were selected for the present study in one group, as it has shown best for the Vata Vyadhis. Here local Abhyanga was given with Bala Taila because Bala Taila and Nadi Sweda are having Vatashamaka and Rasayana properties. While in the case of another group, Guggulu gold along with gum shallaki followed by local Abhyanga and Nadi Sweda were given to the patients.

Keywords: Vridhavastha, Dhatus Kshaya, Sandhigata Vata Abhyanga, Vatashamaka, Rasayana, Guggulu gold, Gum Shallaki, Nadi Sweda

\section{INTRODUCTION}

In Vridhavastha, most of the Dhatus undergo Kshaya, which in turn leads to Vataprakopa and thus making individuals prone to many diseases. Among these diseases, Sandhigata Vata is one type of Vata-Vyadhi, which is the commonest form and occurs mainly due to sitting jobs, air conditioner atmosphere, lack of proper healthy diet, travelling and old age etc. Sandhigata Vata is one of the most common Vatavyadhi, which can be correlated with osteoarthritis. The prevalence rate of Osteoarthritis is about $14.8 \%$, in which knee osteoarthritis prevalence rate is $10.8 \%$ which is more than the arthritis of other joints ${ }^{1}$. The incidence of osteoarthritis in India is as high as $12 \%$. It is estimated that approximately four out of 100 people are affected by it. Osteoarthritis is the most common articular disorder which begins asymptomatically in the $2^{\text {nd }} \& 3^{\text {rd }}$ decades and is extremely common by age 70 . Almost all persons by age 40 have some pathologic change in weight-bearing joint $^{1}$. $25 \%$ of females \& $16 \%$ of males have symptomatic osteoarthritis. Acharya Charaka has mentioned "Sandhi Gataanila" 2, which means Vata gets located in the Sandhi and thereafter results in Sandhigatavata. Allopathic treatment has its limitation in managing this disease. It can provide either conservative or surgical treatment and can only subside the pain but not cure the cause of diseases. While in traditional life science, Ayurveda has the most effective solution over this. Local Abhyanga and Nadi Sweda were selected for the present study as it has shown best for the Vata
Vyadhis. Here local Abhyanga was given with Bala Taila because Bala Taila and Nadi Sweda are having Vatashamaka and Rasayana properties. In another group Guggulu gold along with gum shallaki, local Abhyanga and Nadi Sweda were given to the patients.

\section{Aim \& Objectives}

- To observe the effect of Guggulu gold along with gum shallaki followed by Abhyanga, Nadi Swedana in Sandhigata Vata.

- To observe the effect of only Abhyanga and Nadi Swedana in Sandhigata Vata.

- To compare the difference of results in the above treatment groups.

Material \& Methods: - 50 Patients, suffering from Osteoarthritis, were selected from O.P.D. and I.P.D. of DAC, Jal Punjab.

\section{Inclusion Criteria}

- Classical signs and symptoms of Sandhigatavata are Shula, Shotha, Stambha, Sparsha-asahyata, Sphutana, Akunchana Prasarana Vedana etc. at the joints ${ }^{2}$.

- Patients between the age group of 40 - 75 years.

- Patients without any anatomical deformity were included.

\section{Exclusion Criteria:}

- Patients below 40 and above 75 years of age.

- Patients suffering from a disease like D.M, Carcinoma, Psoriatic arthritis, Vata Rakta, Phiranga, S.L.E., Polymyalgia Rheumatica, 
kidney failure or any renal disease \&Tuberculosis are excluded.

\section{Grouping}

Group A: Patients were treated by local Abhyanga with Bala Taila and Nadi Swedana with Dashamoola Kwatha along with Guggulu gold and gum shallaki ${ }^{3} 2$ Vati twice a day were given to the patient for 30 days with lukewarm water.

Group B: Patients were treated by local Abhyanga with BalaTaila and Nadi Swedana with Dashamula Kwatha for 21 days.

\section{Observations}

A total of 50 patients were registered (group A- $31 \&$ group B-18), amongst them in group A, 26 patients had completed the treatment and 06 were drop out.
However, in group B, 14 patients had completed and 04 were drop out.

In this study, a maximum of $45 \%$ patients was found in 45 - 55 years of age group, $59 \%$ were female, $94 \%$ were Hindu, $97 \%$ were married, $37 \%$ were primary educated, $41 \%$ were housewives, $5 \%$ belonged to lower middle class, $82 \%$ were from the urban area, $37 \%$ had Samashana type of habit, $86 \%$ had got the gradual type of onset, $50 \%$ were found in the chronic stage, $86 \%$ were having aggravation of symptoms in the cold season, $67.3 \%$ were having a negative family history, 69.4\% had Madhyama Koshtha, 69.4\% were having regular bowel habit \& $41 \%$ was in a menopausal state of life.

Table 1: Status wise distribution of 50 patients of Sandhigata Vata

\begin{tabular}{|l|l|l|l|}
\hline Status & Group A Patients & Group B Patients & Total \\
\hline Completed & 26 & 14 & 40 \\
\hline Drop out & 06 & 04 & 10 \\
\hline Total & 32 & 18 & 50 \\
\hline
\end{tabular}

Vata-Kapha predominance was found in $55 \%$ of patients, $81.6 \%$ of patients had got Madhyama Sara. Madhyama Samhanana was found in $83.6 \%$ of patients and Pramana Pariksha, Sthaulya was found in a maximum number of patients i.e. $51 \%$ and Madhyama Pramana was found in $33 \%$ of patients, $65.3 \%$ were in Madhyama Satmya \& Avara Vyayama Shakti was found in 53\% patients. The knee is one of the big weight-bearing joints and thus $94 \%$ was found in the involvement of the knee joint. Involvement of other joints i.e. hip, ankle, the shoulder was found $30.6 \%, 6.12 \%$ and $8.16 \%$ respectively, Divaswapna was found prevalent in $65.30 \%$ of patients, Ati Ruksha Ahara was found in $51 \%$ of patients, Ati Sheeta Ahara was found in $40.8 \%$ patients, Ati Vyayama was found in $38.77 \%$ patients, Ati Alpa Ahara was a causative factor in
$32.65 \%$ of patients. Among the risk factors patients of females were $57.14 \%$, obesity was $55.10 \%$, psychological stress was found in prevalent in $28.57 \%$. Apart from this Vata Vriddhi and Vata Prakopa were found in $100 \%$ of patients \& Kaphakshaya was found in $18.36 \%$ of patients.

Among the Chief Complaints Sandhishula was found in all cases. In Sandhigata Vata there will be aggravation of Vata Dosha which is responsible for any kind of Shula Pradhana Vedana. Akunchana Prasaranajanya Vedana \& Hantisandhigati was found more in the patients, which occurs due to aggravation of Vata Dosha and Kaphakshaya. In the chronic stage osteophyte formation occurs due to this sandhishotha was seen in a chronic case of osteoarthritis. (Table-02) 
Table 2: Chief complaints wise distribution of 50 patients of Sandhigata Vata

\begin{tabular}{|l|l|l|l|l|}
\hline Chief complaints & Group A Patients & Group B Patients & Total & Percentage \\
\hline Sandhishula & 31 & 18 & 49 & 100 \\
\hline Sandhishotha & 19 & 10 & 29 & 59.1 \\
\hline Akunchana prasarana vedana & 23 & 13 & 36 & 73.46 \\
\hline Hanti sandhigata & 04 & 04 & 08 & 16.32 \\
\hline Sandhi sphutana & 22 & 11 & 33 & 67.34 \\
\hline Sparshasahyata & 17 & 07 & 24 & 48.9 \\
\hline Vata Purnadruti Sparsha & 08 & 00 & 03 & 6.12 \\
\hline
\end{tabular}

Table 3: Effect of chief complaints in the patients of Sandhigata Vata in Group A

\begin{tabular}{|l|l|l|l|l|l|l|l|}
\hline Symptoms & B.T & A.T & Percentage of Relief & S.D & S.E & t & P \\
\hline Sandhishula & 2.38 & 0.5 & 77.4 & 0.54 & 0.11 & 16.8 & $<0.001$ \\
\hline Sandhishotha & 1.5 & 0.17 & 88.9 & 0.48 & 0.11 & 12.09 & $<0.001$ \\
\hline Akunchana Prasarana Vedana & 1.8 & 0.4 & 77.8 & 0.58 & 0.11 & 12.7 & $<0.001$ \\
\hline Sandhisphutana & 1.9 & 0.6 & 65.9 & 0.45 & 0.09 & 14.00 & $<0.001$ \\
\hline Sandhisparsha-asahatva & 1.5 & 0.12 & 91.3 & 0.6 & 0.15 & 8.7 & $<0.001$ \\
\hline Sandhigraha & 1.5 & 0.1 & 92.3 & 0.5 & 0.17 & 7.8 & $<0.001$ \\
\hline
\end{tabular}

In the case of walking time in group A, the percentage of improvement was $11.15 \%$, while in group B percentage of improvement was found $5.4 \%$, which is insignificant at the level of $p>0.05$. In the case of climbing time in group A, the percentage of relief was $11.88 \%$. While in group $\mathrm{B}$, the percentage of improvement was $9.09 \%$. This result shows statistical significance at the level of $p<0.01$. In group $A$, in the left knee, the joint flexion percentage of relief was $36.31 \%$, while in right knee joint flexion it was
$47.42 \%$. In hip joint flexion (left), the percentage of relief was $38.51 \%$ and, in the hip, the joint flexion (right) percentage of relief was found $36.82 \%$, which is statistically highly significant. In group B, in the left knee, joint flexion, the percentage of relief was found $27.05 \%$ \& in right knee joint flexion, improvement was found $20.15 \%$. While in hip joint flexion (left), the percentage of relief was found $18.85 \%$ \& in hip joint flexion (right), the percentage of relief was found $14.58 \%$ (Table $\underline{3}-\underline{4}$ ).

Table 4: Effect of chief complaints in the patients of Sandhigata Vata in Group B

\begin{tabular}{|l|l|l|l|l|l|l|l|}
\hline Symptoms & B.T & A.T & Percentage of Relief & S.D & S.E & t & P \\
\hline Sandhishula & 2.3 & 0.7 & 68.7 & 0.65 & 0.17 & 9.23 & $<0.001$ \\
\hline Sandhishotha & 1.9 & 0.3 & 84.2 & 0.5 & 0.16 & 10.00 & $<0.001$ \\
\hline Akunchana Prasarana Vedana & 1.6 & 0.45 & 72.2 & 0.4 & 0.12 & 9.83 & $<0.001$ \\
\hline Sandhisphutana & 1.67 & 0.8 & 50.00 & 0.4 & 0.11 & 7.54 & $<0.001$ \\
\hline Sandhisparsha-asahatva & 1.5 & 0.25 & 83.3 & 0.5 & 0.25 & 5.00 & $>0.05$ \\
\hline Sandhigraha & 1.8 & 0.17 & 90.9 & 0.52 & 0.21 & 7.95 & $<0.001$ \\
\hline
\end{tabular}

Table 5: Total Effect of therapy on group A \& Group B

\begin{tabular}{|c|c|c|c|c|}
\hline Gradation & $\begin{array}{l}\text { Group } \\
\text { Patients }\end{array}$ & $\begin{array}{l}\text { Group } \\
\text { Percentage }\end{array}$ & $\begin{array}{ll}\text { Group } & \text { B } \\
\text { Patients } & \end{array}$ & $\begin{array}{ll}\text { Group } & \text { B } \\
\text { Percentage } & \end{array}$ \\
\hline Complete Remission (100\%) & 04 & 15.3 & 01 & 7.14 \\
\hline Maximum improvement (>75-99\%) & 16 & 61.5 & 02 & 14.28 \\
\hline Moderate improvement (>50- 75\%) & 06 & 23.07 & 09 & 64.3 \\
\hline Mild improvement (>25 - 50\%) & 00 & 00 & 02 & 14.3 \\
\hline No improvement $(0-25 \%)$ & 00 & 00 & 00 & 00 \\
\hline
\end{tabular}


In both the groups (A \& B) i.e $15.3 \%$ \& $07.14 \%$ patients achieved complete remission, while $61.5 \%$ \& $14.28 \%$ patients found in maximum improvement and $23.07 \%$ \& $64.28 \%$ were having moderately improvement. No patients found mild improvement in group A whereas $14.28 \%$ mild improvement in group B. No patient was found unchanged in both the groups. The above-mentioned data shows that Guggulu gold along with gum shallaki followed by local Abhyanga and Nadi Swedana i.e. group A has provided better relief in the disease Sandhigata Vata (Osteoarthritis) in the present study.

\section{DISCUSSION}

In this study, $44.89 \%$ of patients were found in the 41 - 50 years of age group. Sandhigata Vata starts at the age of 40 which is the declining stage of Madhya Vaya. According to sex, $59 \%$ were female patients, which indicates that Sandhigata Vata is more common in females and here the lack of estrogen in the premenopausal period also plays an important role. The modern text also reflects the same type of prevalence, Osteoarthritis or Degenerative Joint Disease (DJD) may first appear without symptoms between 20 and 30 years of age ${ }^{3}$ The symptoms, such as pain and inflammation, appear in middle age. Till the age of 55, it occurs equally in both sexes; after 55 the incidence is higher in women 4 .

Among the female patients, $40.8 \%$ were in a menopausal state of life. Due to Dhatukshaya aggravation of Vayu occurs that causes the Sandhigata Vata. In the menopausal condition, the deficiency of female hormone leads to different bone and joints problems. While $87.7 \%$ of patients did not have regular exercise in their routine life. Lack of practice or exercise gradually leads to weight gain which ultimately leads to Sandhigata Vata. Prakruti wise distribution shows that Vata-Kapha predominance was found in $55.10 \%$ of patients, due to Vaya of patients and also intake of the Vata Vardhaka Nidana. Among the different Nidana of the disease, Divaswapna was found in $65.30 \%$. Daytime sleeping increases Kapha and Meda which leads to weight gain and Agnivaishamya which is a common risk factor for Sandhigata Vata. Among the other causative factors Ati Ruksha Ahara (51.02\%), Ati Sheeta Ahara (40.81\%), Ati Vyayama (38.77\%), Ati Alpa Ahara $(32.65 \%)$ also were found. These Nidana played an important role in the aggravation of Vayu and thus causes Sandhigata Vata.

In the case of chronicity, $48.97 \%$ of patients were found in the chronic stage \& $85.71 \%$ were having the gradual type of onset. This data is also supported by literary data. While $85.71 \%$ were suffering from Osteoarthritis in the cold season and this season Vata usually aggravates and causes the disease. A maximum number of patients i.e. $93.88 \%$ had involvement of knee joint. The knee is one of the big weight-bearing joints and thus most affected by Osteoarthritis. Involvement of other joints i.e. hip, ankle, the shoulder was found $30.61 \%, 6.12 \%$ and $8.16 \%$ respectively.

Among the risk factors patients of female sex 57.14\%, obesity $55.10 \%$, psychological stress $28.57 \%$ was found prevalent. These are also supported by the literary data. Osteoarthritis mainly occurs on the weight-bearing joints. Data shows an 11-pound weight reduction, reduce $50 \%$ risk for Osteoarthritis. 5\% weight loss in overweight patients gives an $18 \%$ gain in overall function. So, weight reduction is very important in the case of osteoarthritis.

In both the groups (A \& B) i.e 15.38\% \& $07.14 \%$ patients achieved complete remission, while $61.54 \%$ $\& 14.28 \%$ patients found in maximum improvement and $23.07 \%$ \& $64.28 \%$ were having moderately improvement. No patients found mild improvement in group A whereas $14.28 \%$ mild improvement in group B. No patient was found unchanged in both the groups. In the present study, in affected patients, a knee X-ray was done before and after the treatment, but no changes were observed in any X-ray. No significant change of $\mathrm{S}$. Calcium was found before and after treatment. It shows that there is no direct role of $\mathrm{S}$. Calcium in the aetiology or the prognosis of Osteoarthritis. S. calcium level was found elevated both before and after treatment in female patients of the premenopausal or menopausal period. That may be 
due to the Osteoporotic changes of bones, due to lack of oestrogen hormone.

\section{Probable Mode of Action}

Sandhigata Vata is Madhyama Roga Margagata Vatika disorders in which vitiated Vata gets lodged in Sandhi. Hence to treat Sandhigata Vata drugs acting on both Vata and Asthi should be selected. According to Charaka, in Asthi Dhatu Dushti the treatment should be given Tikta Dravya Ghrita and Kshira. In Panchatikta Ghrita Guggulu predominance of Tikta Rasa is there.

Tikta Rasa has Vayu and Akasha Mahabhuta in dominance. Hence it has got affinity towards the body elements like Asthi having Vayu and Akasha Mahabhuta in dominance. Though, Tikta Rasa aggravates Vayu which may enhance the pathogenic process of Sandhigata Vata but, the main principle of Ayurvedic treatment is "Sthanam Jayate Purvam". The main site of Sandhigata Vata is Sandhi which is the site of Shleshaka Kapha. So, by decreasing the Kapha Dosha Tikta Rasa fulfils the principle.

Due to the Ushna property of Guggulu, it is one of the major Vatashamaka Dravya. Due to its Ruksha and Vishada Guna it acts as a Medohara. According to Sushruta, Guggulu has got Lekhana property which helps in reducing body weight. Due to its Katu Rasa it acts as a Deepana. This help in the improvement of the general condition of the patient. Purana Guggulualso acts as a Rasayana which may help to prevent any degenerative change in the body. Pharmacologically Guggulu has got the properties of anti-inflammatory, immunomodulatory and antilipidaemic action.

On the overall effect of the Guggulu gold along with gum shallaki, it has been found that the drug is predominant in Ushna Virya which helps in the pacification of aggravated Vata and subside the pain. Snehana pacifies the Vata, softens the body and eliminates the accumulated Malas. Swedana relieves the stiffness, heaviness and coldness of the body and produces sweating. By the process of Snehana and Swedana, the blood vessels of skin become dilated and local circulation of blood will be increased. The medicine applied locally is also absorbed by the skin and exerts its effects locally.

\section{CONCLUSION}

Sandhigata Vata is one of the Vata Vikara \& it is Yapya Vyadhi. Sandhigata Vata vis-à-vis Osteoarthritis is multi-factorial, non-inflammatory degenerative joint disorder.

The data shows that Guggulu gold along with gum shallakifollowed by local Abhyanga and Nadi Swedana i.e. group A has provided better relief in the disease Sandhigata Vata (Osteoarthritis) in the present study. In group A, $15.38 \%$ of patients achieved complete remission, while $61.54 \%$ of patients found maximum improvement and $23.07 \%$ were having moderately improvement. No patients were found unchanged and had mild improvement. In group B, $07.14 \%$ of patients obtained complete remission, while $64.28 \%$ of patients were having moderate improvement, whereas $14.28 \%$ of patients each were having maximum improvement and mild improvement. No patient was found unchanged. There was no apparent change was observed in the $\mathrm{x}$-ray before and after treatment. The present study reveals that the selected management have a potential effect on Sandhigatavata with the added advantage of being free from side effects. 
Figure 1: Comparative results in both the groups (Group A \& Group B)

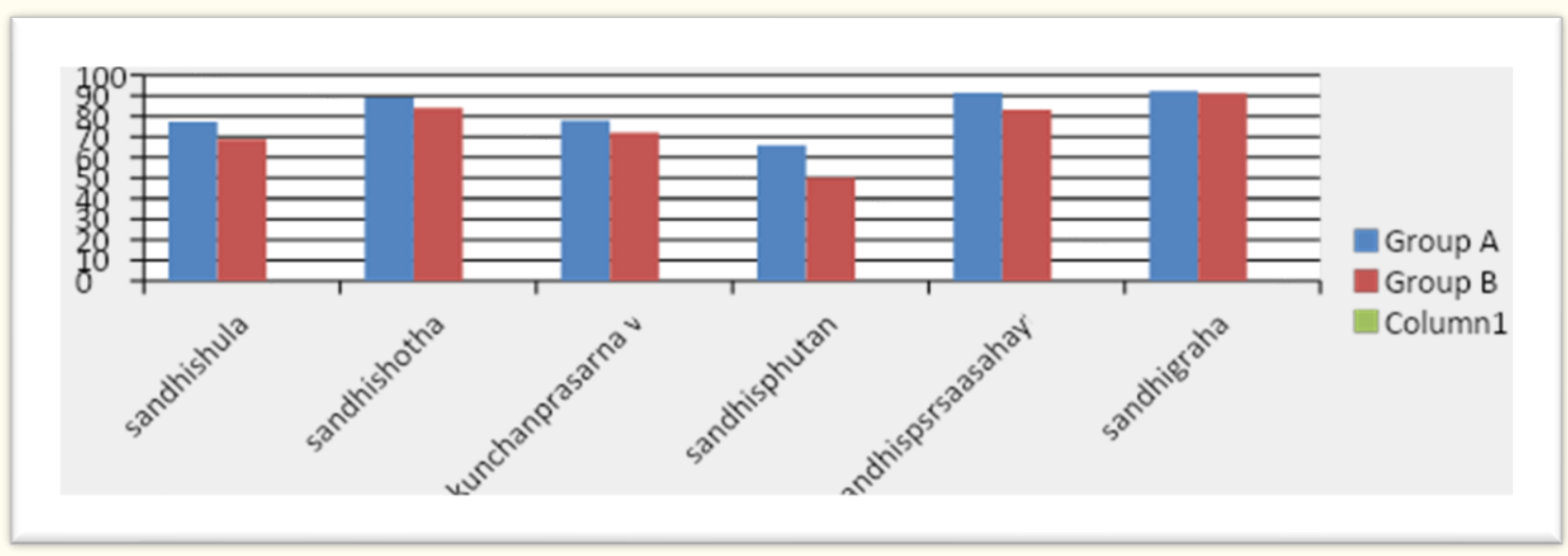

\section{REFERENCES}

1. Ch. 321. 15th Edition 1987. Harrison's Principles of Internal Medicine. [Google Scholar]

2. Acharya Vaidya Jadavaji Trikamji., editor. Chaukhabha Sanskrita Sansthan.37. Vol. 28. Varanasi: Chikitsasthan; Agnivesha, Charaka Samhita, with commentary Chakrapanidatta; p. 618.[Google Scholar]

3. Kumar \& Clark Clinical Medicine. 6th Edition. p. 551.

Ch. 10. [Google Scholar]

4. Ibid. (1), Ch. 321. :1987. [Google Scholar]

5. Ibid. (2) Sutrasthan. 26(5):144. [Google Scholar]

6. Rose \& Wilson, Anatomy \& Physiology in Health \& Illness-Elsevier Churchill Livingstone. Ch. 11.274. [Google Scholar]

\section{Source of Support: Nil \\ Conflict of Interest: None Declared}

How to cite this URL: Nishu Raina: Clinical Study Of Guggulu Gold And Gum Shallaki Along With Panchkarma Therapies In The Management Of Sandhighata Vata W.S.R Osteoarthritis. International Ayurvedic Medical Journal \{online\} 2021 \{cited September 2021\} Available from: http://www.iamj.in/posts/images/upload/3060_3066.pdf 